\title{
$\beta$-Ocimene, a Key Floral and Foliar Volatile Involved in Multiple Interactions between Plants and Other Organisms
}

\author{
Gerard Farré-Armengol 1,2,3,* (D), Iolanda Filella ${ }^{1,2}$, Joan Llusià ${ }^{1,2}$ and Josep Peñuelas ${ }^{1,2}$ (iD \\ 1 CSIC, Global Ecology Unit CREAF-CSIC-UAB, Bellaterra, 08193 Barcelona, Catalonia, Spain; \\ iola@creaf.uab.es (I.F.); j.llusia@creaf.uab.es (J.L.); josep.penuelas@uab.cat (J.P.) \\ 2 CREAF, Cerdanyola del Vallès, 08193 Barcelona, Catalonia, Spain \\ 3 Department of Ecology and Evolution, University of Salzburg, Hellbrunnerstraße 34, 5020 Salzburg, Austria \\ * Correspondence: g.farre@creaf.uab.cat or gerard.farrearmengol@sbg.ac.at; Tel.: +43-662-8044-5517
}

Received: 18 April 2017; Accepted: 3 July 2017; Published: 13 July 2017

\begin{abstract}
Ocimene is a very common plant volatile released in important amounts from the leaves and flowers of many plant species. This acyclic monoterpene can play several biological functions in plants, by potentially affecting floral visitors and also by mediating defensive responses to herbivory. The ubiquity and high relative abundance of $\beta$-ocimene in the floral scents of species from most plant families and from different pollination syndromes (ranging from generalism to specialism) strongly suggest that this terpenoid may play an important role in the attraction of pollinators to flowers. We compiled abundant evidence from published studies that supports $\beta$-ocimene as a generalist attractant of a wide spectrum of pollinators. We found no studies testing behavioural responses of pollinators to $\beta$-ocimene, that could directly demonstrate or deny the function of $\beta$-ocimene in pollinator attraction; but several case studies support that the emissions of $\beta$-ocimene in flowers of different species follow marked temporal and spatial patterns of emission, which are typical from floral volatile organic compound (VOC) emissions that are involved in pollinator attraction. Furthermore, important $\beta$-ocimene emissions are induced from vegetative plant tissues after herbivory in many species, which have relevant functions in the establishment of tritrophic interactions. We thus conclude that $\beta$-ocimene is a key plant volatile with multiple relevant functions in plants, depending on the organ and the time of emission. Experimental behavioural studies on pure $\beta$-ocimene conducted with pollinating insects will be necessary to prove the assumptions made here.
\end{abstract}

Keywords: trans- $\beta$-ocimene; (E)- $\beta$-ocimene; floral scent; dominant VOCs

\section{Introduction}

More than 1700 volatile organic compounds (VOCs) have been identified in the floral scents of flowering plants [1]. The richness of VOCs emitted by flowers is certainly very high. Floral VOCs, however, are not equally distributed across the phylogeny of flowering plants, so that the commonness and predominance of these compounds in floral scents varies widely among species. Common floral VOCs have a widespread phylogenetic distribution, which means that they are present in the floral scents of many species from different plant families. Plants generally synthesize and emit species-specific floral VOC mixtures to attract pollinators by mixing several of these common VOCs [2]. These specific floral VOC mixtures attract specialist pollinators that have evolved an innate preference for them [3] but also provide generalist pollinators with a reliable signal to effectively forage on their floral resources [4]. Some less common floral VOCs are only present in plants that are pollinated by specific pollinator groups with specific innate preferences for those VOCs [5-7]. Some of the 
rarest floral VOCs can constitute very specific and reliable communication channels between specialist pollinators and their host plants, even when they are emitted within a mixture that includes more common VOCs $[3,8]$.

Most floral VOCs range from being relatively common to rare, but some are very common in the floral scents of species from all plant families. These volatiles, which are essentially obligate components of any floral scent, have great potential for attracting pollinators. The commonest floral VOCs, namely benzaldehyde, limonene, $\beta$-ocimene and linalool, are not only very common but are also predominant components of the floral scents of many species [9]. They belong to the two most prominent chemical groups of plant VOCs, the terpenoids and the benzenoids [10,11].

Here we review the current information on the importance of $\beta$-ocimene in plants, focusing especially on its biological functions and its ubiquitous presence in floral scents. We compiled abundant evidence from published studies supporting that $\beta$-ocimene may play a very relevant function as a general pollinator attractant. We further emphasize that $\beta$-ocimene may not only mediate pollinator attraction to flowers but plays several biological functions in plants, which vary depending on the organ and the time of emission.

\section{Biosynthesis of $\beta$-Ocimene}

$\beta$-Ocimene (3,7-dimethyl-1,3,6-octatriene) is a monoterpenoid with the chemical formula $\mathrm{C}_{10} \mathrm{H}_{16}$. It has two stereoisomers, cis- and trans- $\beta$-ocimene (or $(Z)$ - and $(E)-\beta$-ocimene, respectively), which are the cis and trans forms of the central double bond (Figure 1). The trans isomer is more common and more abundantly emitted in floral scents than the cis isomer [1,9]. It is synthesized from the precursors isopentenyl pyrophosphate (IPP) and dimethylallyl pyrophosphate (DMAPP) via the methyl-erythritol-phosphate (MEP) pathway. Monoterpenes are obtained by the transformation of DMAPP and IPP into geranyl diphosphate (GPP) inside the chloroplasts, and the later synthesis of terpene compounds from GPP by enzymes called terpene synthases (TPS), which are very diversified across the phylogeny of the plant kingdom $[10,12-15]$. $\beta$-Ocimene is synthesized by the enzyme $(E)$ - $\beta$-ocimene synthase (with the systematic name geranyl-diphosphate diphosphate-lyase $((E)$ - $\beta$-ocimene-forming)), which transforms GPP into trans- $\beta$-ocimene and diphosphate. $(E)-\beta$-Ocimene synthase produces mostly trans- $\beta$-ocimene $(94-97 \%)$, but other monoterpenes such as cis- $\beta$-ocimene or myrcene are produced in low proportions ( $2-4 \%$ and $1-2 \%$, respectively) [16-19]. Cis- $\beta$-ocimene is thus less common than trans- $\beta$-ocimene in floral scents; it is produced and emitted in small but detectable amounts only in species where trans- $\beta$-ocimene is produced in moderately high amounts.

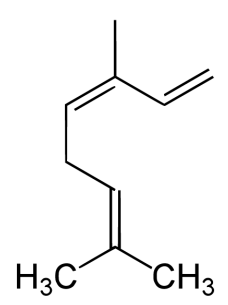<smiles>C=C/C(C)=C/CC=C(C)C</smiles>

cis- $\beta$-ocimene

trans- $\beta$-ocimene

Figure 1. Chemical structure of the two $\beta$-ocimene stereoisomers, cis- and trans- $\beta$-ocimene (also referred to as $(Z)$ - and (E)- $\beta$-ocimene, respectively).

\section{Functions of $\beta$-Ocimene in Flowers}

Ocimene is likely to play major ecological roles in flowers due to its commonness and abundance in floral scents. Trans- $\beta$-ocimene occurs in the floral scents of $71 \%$ of the 90 plant families in the list of identified floral-scent compounds compiled by Knudsen et al. [1]. In our recent metaanalysis of floral scents [9], trans- $\beta$-ocimene occurred in the floral scents of $47.5 \%$ of the 291 plant species 
(Figure 2) and in $75 \%$ of the 63 plant families represented. The presence of this compound in nearly a half of the species that were considered in our study may seem not too much at first glance, but when we look at the other compounds we may see that few compounds present similar levels of occurrence and predominance in floral scents (Figure 2). The ability to emit $\beta$-ocimene from flowers is widely distributed and has appeared and disappeared several times across the phylogeny of flowering plants (Figure 3). It is abundantly emitted by a wide range of plants that are pollinated by various groups of pollinators, including bees [20,21], beetles [22,23], butterflies and moths [22,24,25]. Filella et al. [26] proposed that $\beta$-ocimene was a generalist pollinator attractant, arguing that $\beta$-ocimene was emitted in high proportions by the generalist species Muscari neglectum, Ranunculus gramineus, Euphorbia flavicoma and Iris lutescens. These four species were rare at the study site in a Mediterranean shrubland community and were submitted to strong competition for pollinator visitation by the dominant plant species Rosmarinus officinalis and Thymus vulgaris. The authors also argued that all rare species that co-flowered and had to compete with $R$. officinalis and T. vulgaris emitted floral scents dominated by $\beta$-ocimene, because this volatile compound may help them to effectively attract a wide array of pollinators and thus to compensate for the plants' low abundance. Alternatively, the dominant species, $R$. officinalis and T. vulgaris, may emit more complex floral scents, which are very rich in other terpene compounds [26]. Attracting specialized pollinators that transfer pollen only from the same plant species provides several advantages for plants, compared to relying on a generalized pollination [27]. We could thus hypothesize that several plant species growing as a community reassemble a large community of pollinators by producing a global flower signal, while minor VOCs or other traits could then insure specificity in the flowers visited by pollinators.
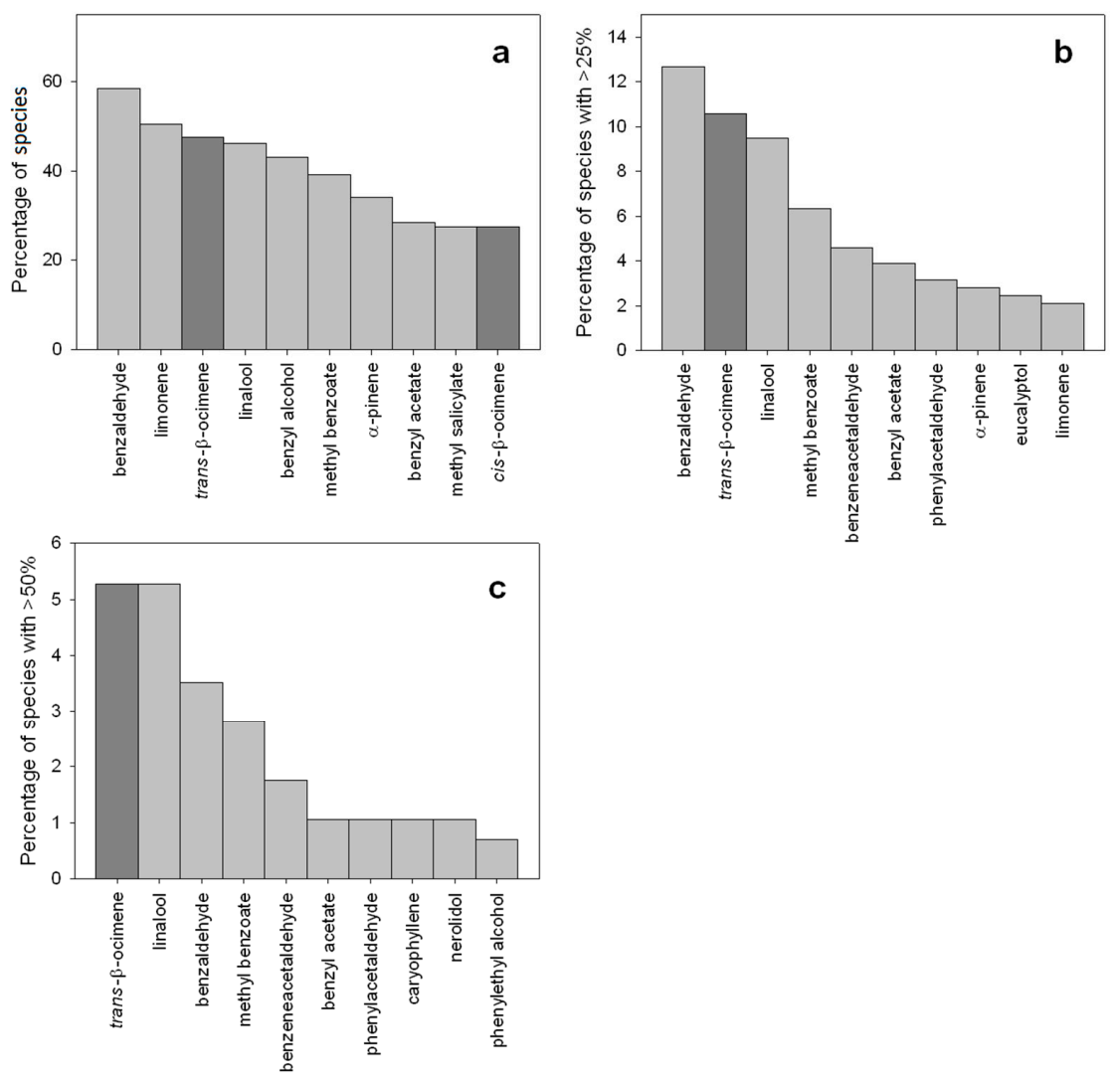

Figure 2. Occurrence and abundance of $\beta$-ocimene in floral scents. Bar charts showing (a) the percentage of plant species with the most common floral volatiles; (b) the percentage of plant species where the most abundant floral volatiles represent more than $25 \%$ of the total floral scent; and (c) the percentage of plant species where the most abundant floral volatiles represent more than $50 \%$ of the total floral scent. 


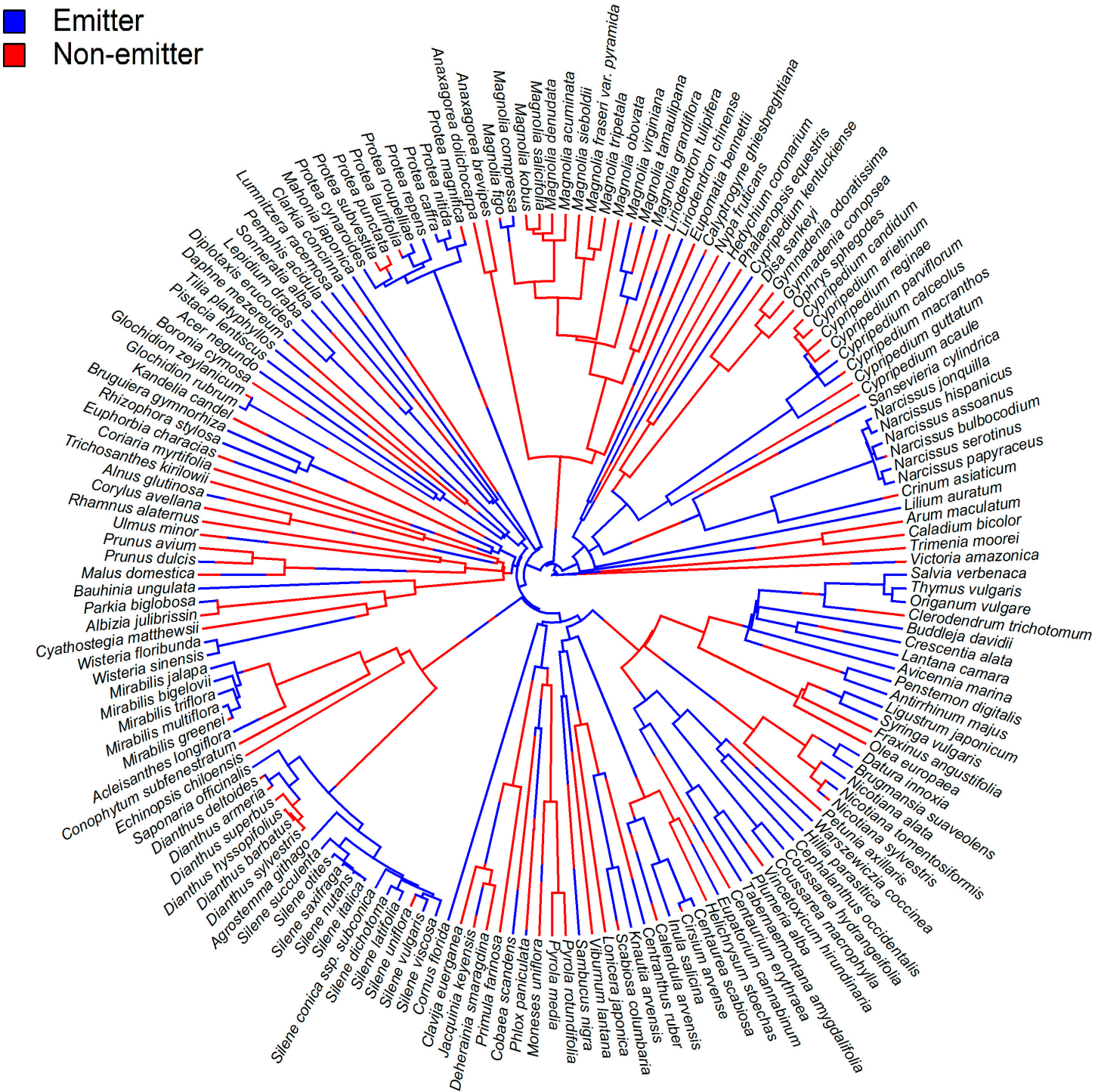

Figure 3. Ancestral phylogenetic reconstruction of floral emissions of trans- $\beta$-ocimene. One thousand trees were simulated with a mapped discrete character with states "Emitter" and "Non-emitter". Trees had an average of 231.716 changes between states. The changes were: 117.436 Emitter $\rightarrow$ Non-emitter and 114.28 Non-emitter $\rightarrow$ Emitter. Mean times spent in each state were: $50.47 \%$ Emitter and $49.53 \%$ Non-emitter.

Multiple evidence supports the role of $\beta$-ocimene in pollinator attraction in addition to its high occurrence in floral scents. $\beta$-Ocimene can effectively attract honeybees and bumblebees $[28,29]$. Animal-pollinated flowers have evolved mechanisms to regulate VOC emissions and make them follow particular spatial and temporal patterns of emission in order to maximize pollinator attraction and pollination success $[14,30]$. Spatial patterns of emission along petals or in particular organs of the flower can resemble visual nectar guides and constitute reliable guides for pollinators to find and reach the nectaries, while normally ensuring pollinator contact with the pollen and the stigmas [31]. Circadian rhythms that make floral scents follow diurnal or nocturnal periods of emission are adapted to match the periods of activity of the respective pollinators [32-39]. Ontogenical changes in floral scent along flower lifespan may also occur because flowers modify or reduce their floral scent once they are pollinated to reduce the costs, to prevent visits by pollinators and other floral visitors that can have harmful effects on floral structures, and to direct pollinator visits to unpollinated flowers [37,40-42]. There are several case studies demonstrating that $\beta$-ocimene emissions of different species show 
patterns of emission similar to those mentioned. Ranunculus acris flowers have a floral scent dominated by $\beta$-ocimene and its petals present emissions that differ quantitatively between the apical and basal regions, paralleling optical nectar-guide patterns that guide pollinators to the nectaries [31]. The flowers of Mirabilis jalapa emit a floral scent that is strongly dominated by trans- $\beta$-ocimene, its main site of emission are the petaloid lobes located at the flower limb, and its emissions describe an evening maximum between 17:00 and 20:00 that matches nicely with the flower opening and the activity of its crepuscular hawkmoth pollinators [36]. The floral scent of snapdragon (Antirrhinum majus) is dominated by trans- $\beta$-ocimene, whose emission follows a diurnal cycle controlled by a circadian clock, with the highest emission rates between 11:00 and 18:00 [16]. Dudareva et al. [16] showed that the rhythmic floral emission of trans- $\beta$-ocimene and other monoterpenes displayed a "free-running" cycle in the absence of environmental cues, with complete independence from light, indicating the circadian nature of its diurnal rhythmicity. The rates of emission of trans- $\beta$-ocimene from the flowers of snapdragon and Satsuma mandarin (Citrus unshiu) vary with floral ontogeny, with maximum emissions when flowers are fully open and mature and need to be pollinated, and decreasing emissions in later periods until fruit development $[16,43]$. Such spatial and temporal patterns of emission indicate a clear involvement of $\beta$-ocimene in the attraction of pollinators to flowers in these species [30]. However, the effects of $\beta$-ocimene on pollinators may be dependent on the context, i.e., on whether it is presented within the correct blend of floral and whole plant volatiles [44], and also with the correct combination of floral and plant traits other than scent.

Different patterns of emission are shown when floral volatiles develop biological functions other than pollinator attraction. For example, the emission of floral volatiles that serve as a defence against herbivores and florivores can be temporally induced after suffering an attack [45,46]; but constitutive floral emissions of these compounds that might interfere with pollination and constitute an unnecessary cost for the plant are generally avoided by animal-pollinated flowers [30,47,48]. Also, some volatile and non-volatile secondary metabolites with antibacterial and antifungal properties that develop defence functions against microbial pathogens are abundant in flowers $[49,50]$; they are constitutively produced and accumulated especially in floral tissues that the plant must protect even at a high cost because they are costly to produce, they are rich in nutrients, and they are important for plant reproduction, like for example nectar [51-53] and pollen [54,55]. Floral emissions of $\beta$-ocimene do not seem to play such roles as far as we read from the literature. Anyway, sometimes single floral volatiles can play multiple roles in flowers (e.g., flower defence and pollinator attraction) [50], and while the correct development of functions such as pollinator attraction or communication with other plant mutualists like predators of herbivores may be dependent on the correct combination with other compounds, some defensive functions might only depend on the presence of single compounds whose effectiveness is only dependent on their own deterrent, toxic [56,57] and antimicrobial properties [58,59] (even if combinations of defensive compounds can potentially show synergistic effects).

\section{Biological Functions of $\beta$-Ocimene Emissions from Non-Floral Tissues}

$\beta$-Ocimene is not only abundantly emitted by plant reproductive structures but is also a common VOC emitted from vegetative plant tissues $[60,61]$. Phytophagous insects can identify the VOC blends that are constitutively emitted by the plants in the community, including $\beta$-ocimene, and use them as chemical cues to identify their host plants $[62,63]$.

$\beta$-Ocimene serves as a chemical cue in several plant species to attract natural enemies of phytophagous insects. Herbivore-infested plants induce increased emissions of VOCs such as $\beta$-ocimene from damaged and undamaged tissues in a systemic defensive response [64-68]. The emission of $\beta$-ocimene can also be induced in undamaged neighboring plants via volatile signals such as cis-jasmone from herbivore-attacked plants [68,69]. Parasitoids and predators of herbivores are attracted to the VOCs emitted from infested plants, which in most cases include important proportions of $\beta$-ocimene, that indirectly help plants to cope with herbivorous attacks in a tritrophic interaction $[70,71]$. The stronger production and emission of $\beta$-ocimene from herbivore-attacked Medicago truncatula 
plants compared to undamaged plants suggest that this compound plays an active role in indirect insect defenses [17]. In addition to its effect on insects, $\beta$-ocimene can also play important roles in plant-plant communication by mediating the induction of genes involved in defense [72,73]. Arimura et al. [72,73] revealed that $\beta$-ocimene and other volatiles emitted by lima bean after spider mite attack elicit the expression of several genes involved in plant defense by activation of the jasmonic acid signalling pathway, enabling these plants to prepare defenses against the spider mites in advance.

\section{Conclusions}

$\beta$-Ocimene is one of the most ubiquitous volatiles in floral scents and we have strong evidence to think that it can play relevant biological roles in flowers. To our knowledge there is no behavioural demonstration that $\beta$-ocimene attracts pollinators, but the abundant and well supported assumptions presented here warrant behavioural studies. There is strong indication that $\beta$-ocimene can play very relevant roles in the attraction of several types of pollinators to the flowers of a diverse array of plants. $\beta$-Ocimene also plays important defensive roles in vegetative plant tissues by mediating tritrophic interactions with parasitoids and predators of herbivores. We thus aim to highlight the importance of $\beta$-ocimene in the establishment of very important biological interactions between plants and beneficial organisms. In summary, $\beta$-ocimene has multiple relevant functions in plants, which vary depending on the organ and the time of emission. In view of the presented lines of indirect evidence, we strongly encourage the inclusion of $\beta$-ocimene alone or in combination with other floral volatiles in coupled gas chromatography electroantennographic detection (GC-EAD) analyses and behavioural tests when conducting future studies in order to provide a solid experimental proof for the assumptions made here.

Acknowledgments: This research was supported by the European Research Council Synergy grant ERC-2013-SyG-610028 IMBALANCE-P, the Spanish Government project CGL2016-79835-P and the Catalan Government grant FI-2013.

Author Contributions: All authors contributed equally to this work.

Conflicts of Interest: The authors declare no conflict of interest.

\section{References}

1. Knudsen, J.T.; Eriksson, R.; Gershenzon, J.; Ståhl, B. Diversity and Distribution of Floral Scent. Bot. Rev. 2006, 72, 1-120. [CrossRef]

2. Negre-Zakharov, F.; Long, M.C.; Dudareva, N. Floral scents and fruit aromas inspired by nature. In Plant-Derived Natural Products; Osbourn, A.E., Lanzotti, V., Eds.; Springer: Berlin, Germany, 2009; pp. 405-431.

3. Grison-pigé, L.; Bessière, J.-M.; Hossaert-McKey, M. Specific attraction of fig-pollinating wasps: Role of volatile compounds released by tropical figs. J. Chem. Ecol. 2002, 28, 283-295. [CrossRef] [PubMed]

4. Wright, G.A.; Lutmerding, A.; Dudareva, N.; Smith, B.H. Intensity and the ratios of compounds in the scent of snapdragon flowers affect scent discrimination by honeybees (Apis mellifera). J. Comp. Physiol. A 2005, 191, 105-114. [CrossRef] [PubMed]

5. Knudsen, J.T.; Tollsten, L. Floral scent in bat-pollinated plants: A case of convergent evolution. Bot. J. Linn. Soc. 1995, 119, 45-57. [CrossRef]

6. Von Helversen, O.; Winkler, L.; Bestmann, H.J. Sulphur-containing "perfumes" attract flower-visiting bats. J. Comp. Physiol. A 2000, 186, 143-153. [CrossRef] [PubMed]

7. Johnson, S.D.; Jürgens, A. Convergent evolution of carrion and faecal scent mimicry in fly-pollinated angiosperm flowers and a stinkhorn fungus. S. Afr. J. Bot. 2010, 76, 796-807. [CrossRef]

8. Grison, L.; Edwards, A.A.; Hossaert-McMey, M. Interspecies variation in floral fragrances emitted by tropical Ficus species. Phytochemistry 1999, 52, 1293-1299. [CrossRef]

9. Farré-Armengol, G.; Filella, I.; Llusià, J.; Peñuelas, J. Deciphering the biotic and climatic factors that determine floral scents: A meta-analysis of floral volatile emissions. Perspect. Plant Ecol. Evol. Syst. 2017. submitted. 
10. Pichersky, E.; Noel, J.P.; Dudareva, N. Biosynthesis of plant volatiles: Nature's diversity and ingenuity. Science 2006, 311, 808-811. [CrossRef] [PubMed]

11. Maffei, M.E. Sites of synthesis, biochemistry and functional role of plant volatiles. S. Afr. J. Bot. 2010, 76, 612-631. [CrossRef]

12. Dudareva, N.; Pichersky, E. Biochemical and Molecular Genetic Aspects of Floral Scents. Plant Physiol. 2000, 122, 627-633. [CrossRef] [PubMed]

13. Dudareva, N.; Pichersky, E.; Gershenzon, J. Biochemistry of Plant Volatiles. Plant Physiol. 2004, 135, 1893-1902. [CrossRef] [PubMed]

14. Muhlemann, J.K.; Klempien, A.; Dudareva, N. Floral volatiles: From biosynthesis to function. Plant Cell Environ. 2014, 37, 1936-1949. [CrossRef] [PubMed]

15. Degenhardt, J.; Köllner, T.G.; Gershenzon, J. Monoterpene and sesquiterpene synthases and the origin of terpene skeletal diversity in plants. Phytochemistry 2009, 70, 1621-1637. [CrossRef] [PubMed]

16. Dudareva, N.; Martin, D.; Kish, C.M.; Kolosova, N.; Gorenstein, N.; Fäldt, J.; Miller, B.; Bohlmann, J. (E)- $\beta$-Ocimene and Myrcene Synthase Genes of Floral Scent Biosynthesis in Snapdragon: Function and Expression of Three Terpene Synthase Genes of a New Terpene Synthase Subfamily. Plant Cell 2003, 15, 1227-1241. [CrossRef] [PubMed]

17. Navia-Giné, W.G.; Yuan, J.S.; Mauromoustakos, A.; Murphy, J.B.; Chen, F.; Korth, K.L. Medicago truncatula (E)- $\beta$-ocimene synthase is induced by insect herbivory with corresponding increases in emission of volatile ocimene. Plant Physiol. Biochem. 2009, 47, 416-425. [CrossRef] [PubMed]

18. Arimura, G.-I.; Ozawa, R.; Kugimiya, S.; Takabayashi, J.; Bohlmann, J. Herbivore-Induced Defense Response in a Model Legume. Two-Spotted Spider Mites Induce Emission of (E)- $\beta$-Ocimene and Transcript Accumulation of (E)-ß-Ocimene Synthase in Lotus japonicus. Plant Physiol. 2004, 135, 1976-1983. [CrossRef] [PubMed]

19. Faldt, J.; Arimura, G.; Gershenzon, J.; Takabayashi, J.; Bohlmann, J. Functional identification of AtTPS03 as $(E)$ - $\beta$-ocimene synthase: A monoterpene synthase catalyzing jasmonate- and wound-induced volatile formation in Arabidopsis thaliana. Planta 2003, 216, 745-751. [PubMed]

20. Gerlach, G.; Schill, R. Composition of Orchid Scents Attracting Euglossine Bees. Bot. Acta 1991, 104, $379-384$. [CrossRef]

21. Borg-Karlson, A.-K.; Valterová, I.; Nilsson, L.A. Volatile compounds from flowers of six species in the family Apiaceae: Bouquets for different pollinators? Phytochemistry 1994, 35, 111-119. [CrossRef]

22. Okamoto, T.; Kawakita, A.; Kato, M. Interspecific variation of floral scent composition in Glochidion and its association with host-specific pollinating seed parasite (Epicephala). J. Chem. Ecol. 2007, 33, 1065-1081. [CrossRef] [PubMed]

23. Dufaÿ, M.; Hossaert-McKey, M.; Anstett, M.C. When leaves act like flowers: How dwarf palms attract their pollinators. Ecol. Lett. 2003, 6, 28-34. [CrossRef]

24. Knudsen, J.T.; Tollsten, L. Trends in floral scent chemistry in pollination syndromes: Floral scent composition in moth-pollinated taxa. Bot. J. Linn. Soc. 1993, 113, 263-284. [CrossRef]

25. Andersson, S.; Nilsson, L.A.A.; Groth, I.; Bergstrom, G. Floral scents in butterfly-pollinated plants: Possible convergence in chemical composition. Bot. J. Linn. Soc. 2002, 140, 129-153. [CrossRef]

26. Filella, I.; Primante, C.; Llusià, J.; Martín González, A.M.; Seco, R.; Farré-Armengol, G.; Rodrigo, A.; Bosch, J.; Peñuelas, J. Floral advertisement scent in a changing plant-pollinators market. Sci. Rep. 2013, 3, 3434. [CrossRef] [PubMed]

27. Schiestl, F.P.; Schl, P.M. Floral Isolation, Specialized Pollination, and Pollinator Behavior in Orchids. Annu. Rev. Entomol. 2009, 54, 425-446. [CrossRef] [PubMed]

28. Granero, A.M.; Guerra Sanz, J.M.; Egea Gonzalez, F.J.; Martinez Vidal, J.L.; Dornhaus, A.; Ghani, J.; Serrano, A.R.; Chittka, L. Chemical compounds of the foraging recruitment pheromone in bumblebees. Naturwissenschaften 2005, 92, 371-374. [CrossRef] [PubMed]

29. Pecetti, L.; Tava, A.; Felicioli, A.; Pinzauti, M.; Piano, E. Effect of three volatile compounds from lucerne flowers on their attractiveness towards pollinators. Bull. Insectol. 2002, 55, 21-27.

30. Farré-Armengol, G.; Filella, I.; Llusia, J.; Peñuelas, J. Floral volatile organic compounds: Between attraction and deterrence of visitors under global change. Perspect. Plant Ecol. Evol. Syst. 2013, 15, 56-67. [CrossRef]

31. Bergström, G.; Dobson, H.E.M.; Groth, I. Spatial fragrance patterns within the flowers of Ranunculus acris (Ranunculaceae). Plant Syst. Evol. 1995, 195, 221-242. [CrossRef] 
32. Morinaga, S.I.; Kumano, Y.; Ota, A.; Yamaoka, R.; Sakai, S. Day-night fluctuations in floral scent and their effects on reproductive success in Lilium auratum. Popul. Ecol. 2009, 51, 187-195. [CrossRef]

33. Dötterl, S.; Jahreiß, K.; Jhumur, U.S.; Jürgens, A. Temporal variation of flower scent in Silene otites (Caryophyllaceae): A species with a mixed pollination system. Bot. J. Linn. Soc. 2012, 169, 447-460. [CrossRef]

34. Okamoto, T.; Kawakita, A.; Kato, M. Floral adaptations to nocturnal moth pollination in Diplomorpha (Thymelaeaceae). Plant Species Biol. 2008, 23, 192-201. [CrossRef]

35. Dötterl, S.; Wolfe, L.M.; Jürgens, A. Qualitative and quantitative analyses of flower scent in Silene latifolia. Phytochemistry 2005, 66, 203-213. [CrossRef] [PubMed]

36. Effmert, U.; Große, J.; Röse, U.S.R.; Ehrig, F.; Kägi, R.; Piechulla, B. Volatile composition, emission pattern, and localization of floral scent Emission in Mirabilis jalapa (Nyctaginaceae). Am. J. Bot. 2005, 92, 2-12. [CrossRef] [PubMed]

37. Rodriguez-Saona, C.; Parra, L.; Quiroz, A.; Isaacs, R. Variation in highbush blueberry floral volatile profiles as a function of pollination status, cultivar, time of day and flower part: Implications for flower visitation by bees. Ann. Bot. 2011, 107, 1377-1390. [CrossRef] [PubMed]

38. Raguso, R.A.; Levin, R.A.; Foose, S.E.; Holmberg, M.W.; McDade, L.A. Fragrance chemistry, nocturnal rhythms and pollination "syndromes" in Nicotiana. Phytochemistry 2003, 63, 265-284. [CrossRef]

39. Hoballah, M.E.; Stuurman, J.; Turlings, T.C.J.; Guerin, P.M.; Connétable, S.; Kuhlemeier, C. The composition and timing of flower odour emission by wild Petunia axillaris coincide with the antennal perception and nocturnal activity of the pollinator Manduca sexta. Planta 2005, 222, 141-150. [CrossRef] [PubMed]

40. Negre, F.; Kish, C.M.; Boatright, J.; Underwood, B.; Shibuya, K.; Wagner, C.; Clark, D.G.; Dudareva, N. Regulation of Methylbenzoate Emission after Pollination in Snapdragon and Petunia Flowers. Plant Cell 2003, 15, 2992-3006. [CrossRef] [PubMed]

41. Schiestl, F.P.; Ayasse, M. Post-pollination emission of a repellent com-pound in a sexually deceptive orchid: A new mechanism for maximisingreproductive success? Oecologia 2001, 126, 531-534. [CrossRef] [PubMed]

42. Muhlemann, J.K.; Waelti, M.O.; Widmer, A.; Schiestl, F.P. Postpollination Changes in Floral Odor in Silene latifolia: Adaptive Mechanisms for Seed-Predator Avoidance? J. Chem. Ecol. 2006, 32, 1855-1860. [CrossRef] [PubMed]

43. Shimada, T.; Endo, T.; Fujii, H.; Hara, M.; Omura, M. Isolation and characterization of (E)- $\beta$-ocimene and 1,8 cineole synthases in Citrus unshiu Marc. Plant Sci. 2005, 168, 987-995. [CrossRef]

44. Kárpáti, Z.; Knaden, M.; Reinecke, A.; Hansson, B.S. Intraspecific Combinations of Flower and Leaf Volatiles Act Together in Attracting Hawkmoth Pollinators. PLoS ONE 2013, 8, e72805. [CrossRef] [PubMed]

45. Farré-Armengol, G.; Filella, I.; Llusia, J.; Primante, C.; Peñuelas, J. Enhanced emissions of floral volatiles by Diplotaxis erucoides (L.) in response to folivory and florivory by Pieris brassicae (L.). Biochem. Syst. Ecol. 2015, 63, 51-58. [CrossRef]

46. Theis, N.; Kesler, K.; Adler, L.S. Leaf herbivory increases floral fragrance in male but not female Cucurbita pepo subsp. texana (Cucurbitaceae) flowers. Am. J. Bot. 2009, 96, 897-903. [CrossRef] [PubMed]

47. Kessler, A.; Halitschke, R.; Poveda, K. Herbivory-mediated pollinator limitation: Negative impacts of induced volatiles on plant-pollinator interactions. Ecology 2011, 92, 1769-1780. [CrossRef] [PubMed]

48. Kessler, A.; Halitschke, R. Testing the potential for conflicting selection on floral chemical traits by pollinators and herbivores: Predictions and case study. Funct. Ecol. 2009, 23, 901-912. [CrossRef]

49. Junker, R.R.; Loewel, C.; Gross, R.; Dötterl, S.; Keller, A.; Blüthgen, N. Composition of epiphytic bacterial communities differs on petals and leaves. Plant Biol. 2011, 13, 918-924. [CrossRef] [PubMed]

50. Huang, M.; Sanchez-moreiras, A.M.; Abel, C.; Sohrabi, R.; Lee, S.; Gershenzon, J.; Tholl, D. The major volatile organic compound emitted from Arabidopsis thaliana flowers, the sesquiterpene (E)- $\beta$-caryophyllene, is a defense against a bacterial pathogen. New Phytol. 2012, 193, 997-1008. [CrossRef] [PubMed]

51. Raguso, R.A. Why are some floral nectars scented? Ecology 2004, 85, 1486-1494. [CrossRef]

52. Carter, C.; Thornburg, R.W. Is the nectar redox cycle a floral defense against microbial attack? Trends Plant Sci. 2004, 9, 320-324. [CrossRef] [PubMed]

53. Adler, L.S. The ecological significance of toxic nectar. Oikos 2000, 91, 409-420. [CrossRef]

54. Basim, E.; Basim, H.; Özcan, M. Antibacterial activities of Turkish pollen and propolis extracts against plant bacterial pathogens. J. Food Eng. 2006, 77, 992-996. [CrossRef]

55. Dobson, H.E.M.; Bergström, G. The ecology and evolution of pollen odors. Plant Syst. Evol. 2000, $222,63-87$. [CrossRef] 
56. Gershenzon, J.; Dudareva, N. The function of terpene natural products in the natural world. Nat. Chem. Biol. 2007, 3, 408-414. [CrossRef] [PubMed]

57. Kessler, D.; Baldwin, I.T. Making sense of nectar scents: The effects of nectar secondary metabolites on floral visitors of Nicotiana attenuata. Plant J. 2007, 49, 840-854. [CrossRef] [PubMed]

58. Tripathi, N.N.; Mishra, A.K.; Tripathi, S. Antibacterial potential of plant volatile oils: A review potential. Proc. Natl. Acad. Sci. India Sect. B Biol. 2011, 81, 23-68.

59. Utama, I.M.S.; Wills, R.B.H.; Ben-Yehoshua, S.; Kuek, C. In Vitro Efficacy of Plant Volatiles for Inhibiting the Growth of Fruit and Vegetable Decay Microorganisms. J. Agric. Food Chem. 2002, 50, 6371-6377. [CrossRef] [PubMed]

60. Hansen, U.; Seufert, G. Terpenoid emission from Citrus sinensis (L.) OSBECK under drought stress. Phys. Chem. Earth 1999, 42, 681-687. [CrossRef]

61. Wang, Y.F.; Owen, S.M.; Li, Q.J.; Peñuelas, J. Monoterpene emissions from rubber trees (Hevea brasiliensis) in a changing landscapeand climate: Chemical speciation andenvironmental control. Glob. Chang. Biol. 2007, 13, 2270-2282. [CrossRef]

62. Rostelien, T.; Borg-Karlson, A.K.; Mustaparta, H. Selective receptor neurone responses to $E$ - $\beta$-ocimene, $\beta$-myrcene, $E, E$ - $\alpha$-farnesene and homo-farnesene in the moth Heliothis virescens, identified by gas chromatography linked to electrophysiology. J. Comp. Physiol. A 2000, 186, 833-847. [CrossRef] [PubMed]

63. Kariyat, R.R.; Mauck, K.E.; Balogh, C.M.; Stephenson, A.G.; Mescher, M.C.; De Moraes, C.M. Inbreeding in horsenettle (Solanum carolinense) alters night-time volatile emissions that guide oviposition by Manduca sexta moths. Proc. R. Soc. B Biol. Sci. 2013, 280, 20130020. [CrossRef] [PubMed]

64. Loughrin, J.H.; Manukian, A.; Heath, R.R.; Turlings, T.C.; Tumlinson, J.H. Diurnal cycle of emission of induced volatile terpenoids by herbivore-injured cotton plants. Proc. Natl. Acad. Sci. USA 1994, 91, 11836-11840. [CrossRef] [PubMed]

65. Miresmailli, S.; Gries, R.; Gries, G.; Zamarc, R.H.; Isman, M.B. Herbivore-induced plant volatiles allow detection of Trichoplusia ni (Lepidoptera: Noctuidae) infestation on greenhouse tomato plants. Pest Manag. Sci. 2010, 66, 916-924. [CrossRef] [PubMed]

66. Copolovici, L.; Kännastea, A.; Remmel, T.; Niinemets, Ü. Volatile organic compound emissions from Alnus glutinosa under interacting drought and herbivory stresses. Environ. Exp. Bot. 2014, 100, 55-63. [CrossRef]

67. Miresmailli, S.; Gries, R.; Gries, G.; Zamarc, R.H.; Isman, M.B. Population density and feeding duration of cabbage looper larvae on tomato plants alter the levels of plant volatile emissions. Pest Manag. Sci. 2011, 68, 101-107. [CrossRef] [PubMed]

68. Pickett, J.A.; Rasmussen, H.B.; Woodcock, C.M.; Matthes, M.; Napier, J.A. Plant stress signalling: Understanding and exploiting plant-plant interactions. Biochem. Soc. Trans. 2003, 31, 123-127. [CrossRef] [PubMed]

69. Birkett, M.A.; Campbell, C.A.M.; Chamberlain, K.; Guerrieri, E.; Hick, A.J.; Martin, J.L.; Matthes, M.; Napier, J.A.; Pettersson, J.; Pickett, J.A.; et al. New roles for cis-jasmone as an insect semiochemical and in plant defense. Proc. Natl. Acad. Sci. USA 2000, 97, 9329-9334. [CrossRef] [PubMed]

70. De Moraes, C.M.; Lewis, W.J.; Paré, P.W.; Alborn, H.T.; Tumlinson, J.H. Herbivore-infested plants selectively attract parasitoids. Nature 1998, 393, 570-573. [CrossRef]

71. De Moraes, C.; Mescher, M.C.; Tumlinson, J.H. Caterpillar-induced nocturnal plant volatiles repel conspecific females. Nature 2001, 410, 577-580. [CrossRef] [PubMed]

72. Arimura, G.; Ozawa, R.; Shimoda, T.; Nishioka, T.; Boland, W.; Takabayashi, J. Herbivory-induced volatiles elicit defence genes in lima bean leaves. Nature 2000, 406, 512-515. [PubMed]

73. Arimura, G.; Ozawa, R.; Nishioka, T.; Boland, W.; Koch, T.; Kühnemann, F.; Takabayashi, J. Herbivore-induced volatiles induce the emission of ethylene in neighboring lima bean plants. Plant J. 2002, 29, 87-98. [CrossRef] [PubMed]

(c) 2017 by the authors. Licensee MDPI, Basel, Switzerland. This article is an open access article distributed under the terms and conditions of the Creative Commons Attribution (CC BY) license (http:// creativecommons.org/licenses/by/4.0/). 